\title{
POSITIVE STIGMA OF THE PEOPLE WITH DISABILITIES IN THE CZECH REPUBLIC AND BULGARIA
}

\author{
Vesela Kazashka, Dora Levterova, Margarita Ruseva, Paisii Hilendarski University of Plovdiv, \\ ruseva_margarita@abv.bg
}

\begin{abstract}
Communication requires unconditional respect for the other. Acknowledging the qualities of the people is a basis for good communication. Communication starts when you accept the people the way they are. The social, economic and technical development provides opportunities for good professional realization of people with special educational needs. The resistance, striving for "survival" and successful "introduction" into the social life are a prerequisite for success. The people who are stigmatized and their families are aware that once they have been labeled, they should have to overcome this stigma and to take the maximum possible good out of this label. Positive stigma stimulates the people with disabilities seek more contacts, to become more independent and to realize themselves adequately in the social life. The survey of attitudes and motivation scale contact with people with disabilities give reliable information about what is the attitude of students towards people with disabilities and what were their contacts. The successful integration into society of people with special educational needs depends also on the perceptions and attitudes of the professionals who work with them too. Undoubtedly, the attitudes and models for the disabled people change and will continue to change. In this context the disabled people should develop social identity and public awareness, but not only in their stigmatized group, but in a broad social aspect.
\end{abstract}

JEL Classification Number: I31, DOI: 10.12955/cbup.2013.51

Keywords: communication, people with disabilities, positive stigma

\section{Introduction}

Communication is an invitation to the other person to reveal himself. If this process is not two-sided and mutual this would make the self-revelation difficult. Communication implies also sincerity. In communicating with people with disabilities it is important not to emphasize on the differences, and the person with disability should not feel tolerated or pitied, but he has to know that he is equal.

Communication and contacts with people with disabilities are not confined only to applying verbal and non-verbal skills for coding and decoding of information. The social skills related to establishing and initiating, maintaining and implementing of effective social contacts with people with disabilities, are not well enough mastered. Very often people without disabilities are embarrassed from or avoid contacts with people with disabilities. This is also a result of the stereotypes, which people have created, and also of the frequency of communications with people with disabilities. If there are no such contacts, it is very difficult to overcome the stereotypes and the communication is smooth, and the opposite - in case of frequent meetings with people with disabilities communication is easier. Effective 
communication implies and requires also synchrony of the coded and decoded signs and symbols of the communicator and the recipient. Here it is necessary to use one and the same understandable and simple language for the participants in the communication process. Signs and symbols have different dimensions in the communication processes. Verbal and non-verbal aspects of communication are of major importance.

\section{Data and methodology}

The goal of this work is to study the determinants of integration of the people with disabilities, encoded in the communication model of the future psychologists in Bulgaria and the Czech Republic with people with disabilities.

Object of this empirical survey are the social and pedagogical conditions of integration of the people with disabilities. Subject of the offered social and pedagogical survey are the components and functions of the integration of people with disabilities, the qualitative characteristics of the parameters of the value system of the people with disabilities and particularly the process of communication with people with disabilities.

The main focus question of the survey is whether "The Contact with Disabled Persons Scale" can be effective in the assessment of the processes of integration of people with disabilities. Is it possible the communication and social contacts with people with disabilities to be related to a respectful and patronizing attitude which is provoked by the existing and imposed stereotypes?

In order to receive an adequate answer to the posed questions, we used a questionnaire developed by Yuker, Hurley (1987), known under the name "Contact with Disabled Persons scale". Later, the questionnaire was modified by Wang (1998) and approbated by Pruet (2004). The questionnaire contains 20 items - test units, each one of them offering an answer graded in several levels. For assessing the size and significance of the contacts of the students from Bulgaria and the Czech Republic, who have had contacts with disabled people, we used a five-point Likert scale. The participants in the survey - 50 students from Bulgaria and 48 students from the Czech Republic, who study in Bachelor's programs in Psychology and Social Pedagogics, were given a form with 20 questions. Each question is supplied with five values with a respective number, as follows:

Table 1: Numbers of answers and numeric code

\begin{tabular}{|l|c|c|c|c|c|}
\hline Answer & Never & Once or twice & Several times & Often & Very often \\
\hline $\begin{array}{l}\text { Numeric } \\
\text { code }\end{array}$ & 1 & 2 & 3 & 4 & 5 \\
\hline
\end{tabular}

Source: Yuker and Hurley (1987)

The items of the Contact with disabled persons scale can be incorporated in the following main aspects: frequency of the various forms of communication; frequency and willingness to share problems, frequency of provision of help by and to disabled people, contacts in home, contacts at work, frequency of expression of various emotional conditions in the contacts with people with disabilities, etc. 


\section{Results and discussion}

In the course of the survey the following analyses were made:

- cluster analysis of the twenty items according to primary data,

- extracting the psychometric characteristics of the Contact with disabled people scale.

The result of the first activity is presented in Figure 1, which shows that the answers to the items of the questionnaire are grouped in end positions in two branches.

To the first branch there are assigned social schemes of communication and contacts with disabled people who are liked, and social scheme of meetings with disabled people, who have been pitied. The latter is indicative of the fact that the existing stereotypes and prejudices exert certain influence. Reasonably, we can accept the statement that the respectful attitude is rather patronizing and it is due to the fact that the students want to help the disabled people in overcoming obstacles in their everyday life and solving their problems.

The second grouping in the upper branch has a narrow position. Here we can see grouping of items connected with home visits, discussing problems of the people without disabilities, as well as discussing problems of the people with disabilities. In this second grouping we can see grouping of items related to the frequency of sharing of meal with people with disabilities.

The lower branch shows grouping of answers to items related to written communication, necessary contacts with people with disabilities who are not liked and/or are unpleasant and appear to be irritants to the others. Another interesting element here is the grouping of the answers to the question related to the mutual work with people with disabilities.

Figure 1: Cluster analysis of the twenty items according to primary data

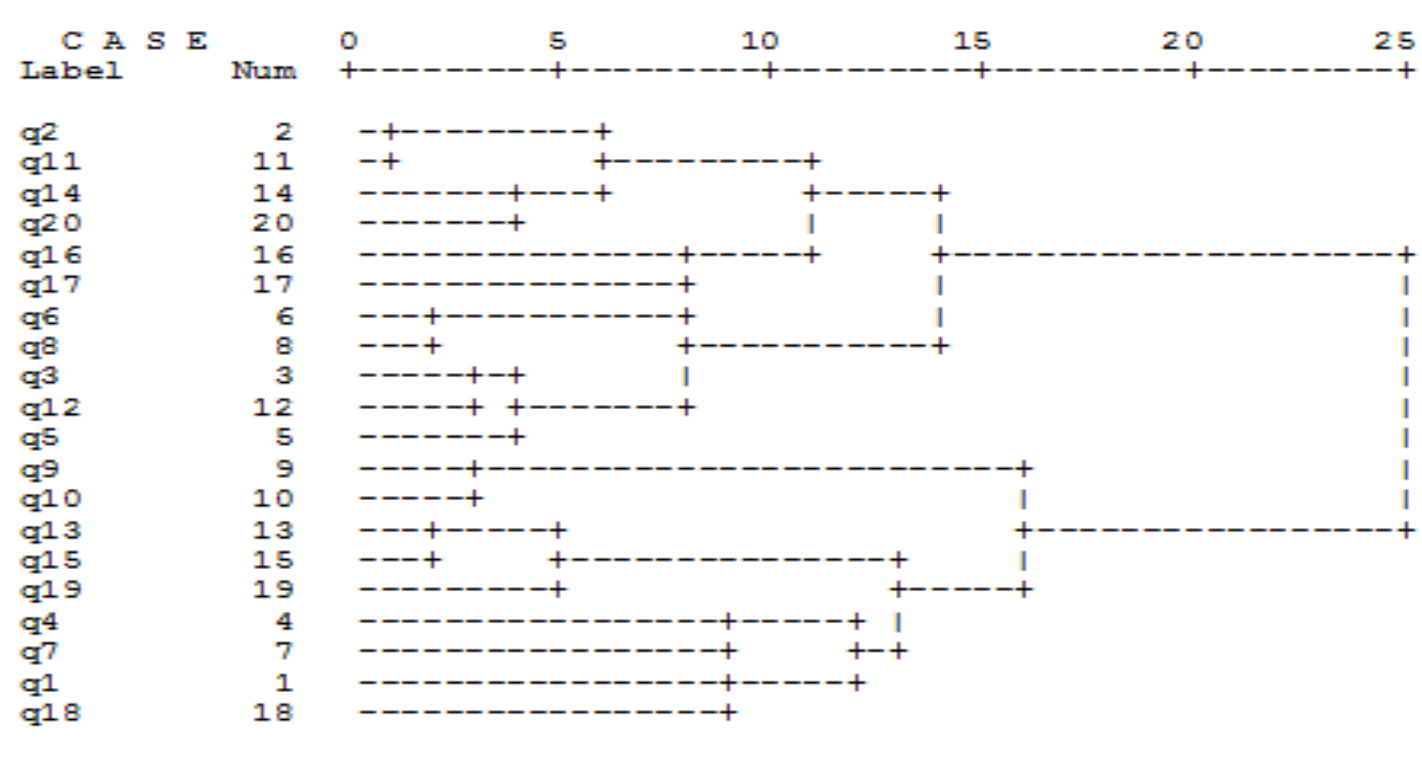

Source: Authors

The result of the second activity consists of clarifying the psychometric characteristics of the Contact with disabled people scale. Figure 2 shows a graphic of the total raw score along the scale, while Table 2 displays the values of the parameters. 
Figure 2: Histogram of the frequency distribution of the total raw score (the raw score is obtained by summing the separate item results on the Contact with disabled people scale)

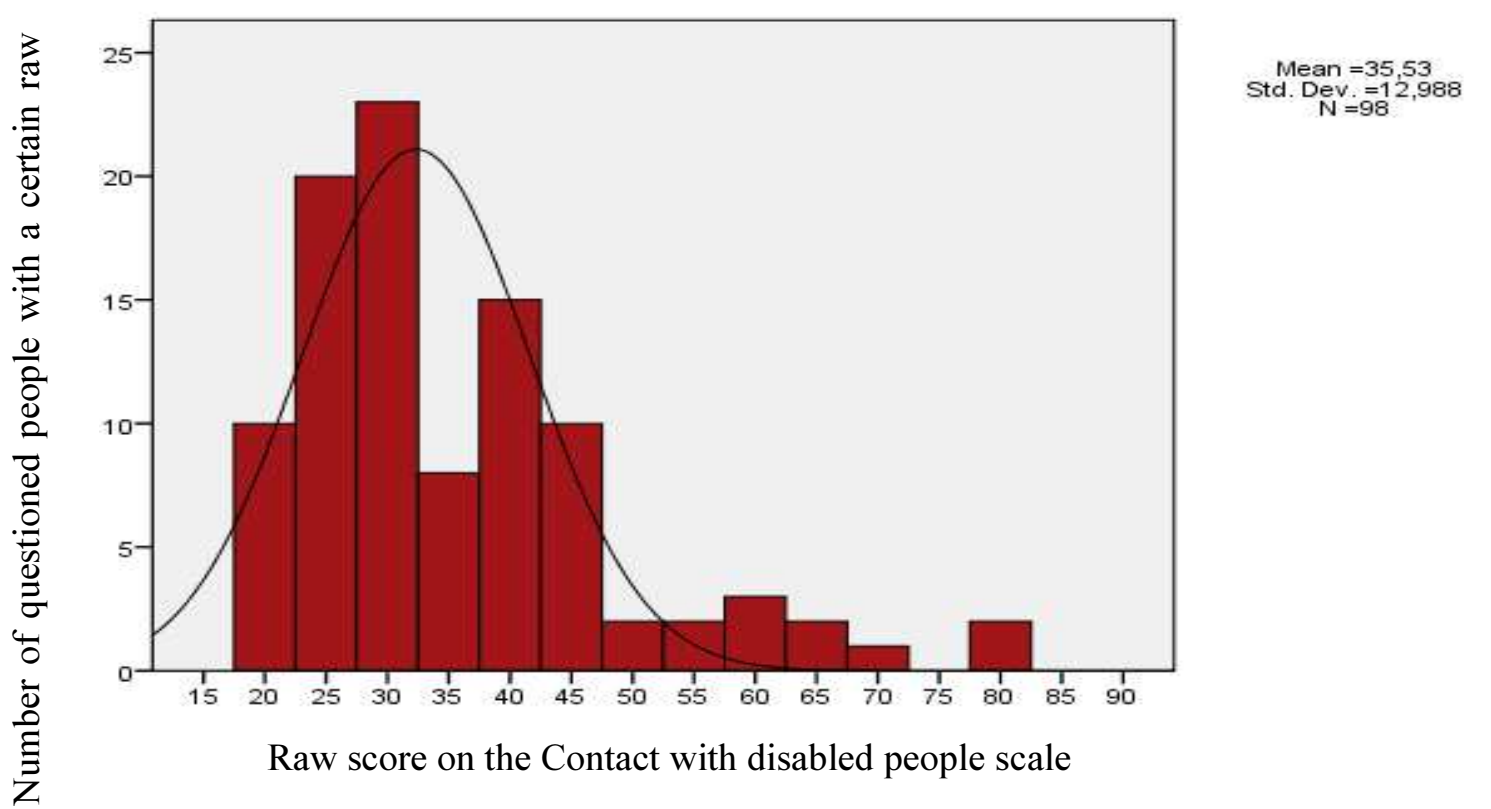

Source: Authors

Table 2: Parameters of the total raw score on the Contact with disabled people scale

\begin{tabular}{|r|c|c|c|c|r|r|r|}
\hline $\begin{array}{c}\text { Total } \\
\text { number of } \\
\text { participants } \\
\text { in the survey }\end{array}$ & $\begin{array}{c}\text { Average } \\
\text { raw } \\
\text { score }\end{array}$ & Mean & $\begin{array}{c}\text { Lower } \\
\text { quartile }\end{array}$ & $\begin{array}{c}\text { Upper } \\
\text { quartile }\end{array}$ & $\begin{array}{c}\text { Standard } \\
\text { deviation }\end{array}$ & $\begin{array}{c}\text { Coefficient } \\
\text { of } \\
\text { asymmetry }\end{array}$ & $\begin{array}{c}\text { Coefficient } \\
\text { of excess }\end{array}$ \\
\hline 98 & 35.534 & 32.000 & 26.000 & 41.250 & 12.988 & 1.436 & 2.346 \\
\hline
\end{tabular}

Source: Authors

In order to find out whether the distribution of the total raw score on the Contact with disabled people scale is normal, we have to define the zero $\left(\mathrm{H}_{0}\right)$ and alternative $\left(\mathrm{H}_{1}\right)$ hypotheses, namely;

$\mathrm{H}_{0}$ : There is no statistically significant difference between this distribution and the normal distribution, as a result of which the distribution of the normal raw score on the Contact with disabled people scale is close to the normal.

$\mathrm{H}_{1}$ : There is a significant difference between the distribution of the raw score on the Contacts with disabled people scale and the normal distribution.

In this aspect, in order to apply the decision-making rule, we use the Kolmogorov-Smirnov test (see Table 3). On the grounds of the data in the table, we can make the conclusion that as the One sample Kolmogorov - Smirnov test $=1.465$; Asymp. Sig $=0.027$ and Asymp.

Sig $>\alpha=0.01$, we accept as correct the zero hypothesis. This means that the distribution of the total raw score on the whole scale is normal. 


\begin{tabular}{|c|c|c|}
\hline & Parameters & Values \\
\hline & Mean & 35.5306 \\
\hline & Std. Deviation & 12.98786 \\
\hline & Kolmogorov-Smirnov Z & 1.465 \\
\hline & Asymp. Sig. (2-tailed) & .027 \\
\hline
\end{tabular}

In order a certain scale to be usable, first of all it has to be reliable and valid. Reliability shows the extent to which the items are coherent about a certain purpose, namely measurement of a preliminary formed construct. Reliability can be defined as the extent to which the studied result of one measurement contains in itself the actual value of the measured characteristic. Validity is related to the fact to what extent the scale measures exactly this construct, in this case - the communication with people with disabilities. The lack of enough reliability of a certain scale is a deficiency, as the raw scores of the scales that are not enough reliable, are considered as a product of an uncontrollable fortuity. The results of the item analysis are presented in Table 4 and Table 5. The first of the two tables shows the more important parameters of each of the items with regards to the raw scores.

Table 4: Parameters (item statistics)

\begin{tabular}{|l|c|c|c|}
\hline \multicolumn{1}{|c|}{ Items } & $\begin{array}{c}\text { Simple } \\
\text { arithmetic } \\
\text { average }\end{array}$ & $\begin{array}{c}\text { Standard } \\
\text { deviation }\end{array}$ & $\begin{array}{c}\text { Number of } \\
\text { surveyed } \\
\text { participants }\end{array}$ \\
\hline $\begin{array}{l}\text { 1. How often did you have a long conversation } \\
\text { with a person with disabilities? }\end{array}$ & 2.53 & 1.114 & 98 \\
\hline $\begin{array}{l}\text { 2.How often did you have a written } \\
\text { communication with people with disabilities? }\end{array}$ & 1.24 & 0.747 & 98 \\
\hline $\begin{array}{l}\text { 3.How often did you have a meal with people } \\
\text { with physical disabilities? }\end{array}$ & 1.72 & 1.033 & 98 \\
\hline $\begin{array}{l}\text { 4.How often have you been a donor to } \\
\text { organizations that help to people with } \\
\text { disabilities? }\end{array}$ & 1.98 & 1.157 & 98 \\
\hline $\begin{array}{l}\text { 5.How often do people with disabilities discuss } \\
\text { their life or their problems with you? }\end{array}$ & 1.78 & 1.099 & 98 \\
\hline $\begin{array}{l}\text { 6.How often do you discuss your life or your } \\
\text { problems with people with disabilities? }\end{array}$ & 1.45 & 0.965 & 98 \\
\hline $\begin{array}{l}\text { 7.How often have you tried to help people with } \\
\text { disabilities to solve their problems? }\end{array}$ & 2.18 & 1.204 & 98 \\
\hline $\begin{array}{l}\text { 8.How often have people with disabilities tried to } \\
\text { help you to solve your problems? }\end{array}$ & 1.31 & 0.817 & 98 \\
\hline $\begin{array}{l}\text { 9.How often have you worked with clients, } \\
\text { students or patients with disabilities in your } \\
\text { work? }\end{array}$ & 1.93 & 1.262 & 98 \\
\hline $\begin{array}{l}\text { 10.How often have you worked with a person } \\
\text { with disabilities? }\end{array}$ & 1.84 & 1.190 & 98 \\
\hline
\end{tabular}




\begin{tabular}{|l|c|c|c|}
\hline $\begin{array}{l}\text { 11. How often does a friend with disabilities visit } \\
\text { your home? }\end{array}$ & 1.26 & 0.693 & 98 \\
\hline $\begin{array}{l}\text { 12.How often have you visited people with } \\
\text { disabilities in their homes? }\end{array}$ & 1.73 & 1.061 & 98 \\
\hline $\begin{array}{l}\text { 13.How often do you meet with a person with } \\
\text { disabilities who you like? }\end{array}$ & 1.90 & 1.135 & 98 \\
\hline $\begin{array}{l}\text { 14.How often do you meet with a person with } \\
\text { disabilities who you do not like? }\end{array}$ & 1.37 & 0.804 & 98 \\
\hline $\begin{array}{l}\text { 15.How often do you meet with a person with } \\
\text { disabilities who you respect? }\end{array}$ & 1.97 & 1.171 & 98 \\
\hline $\begin{array}{l}\text { 16.How often do you meet with a person with } \\
\text { disabilities who you pity? }\end{array}$ & 1.85 & 1.116 & 98 \\
\hline $\begin{array}{l}\text { 17.How often are you irritated or feel confused } \\
\text { by the behavior of a person with disabilities? }\end{array}$ & 1.76 & 1.046 & 98 \\
\hline $\begin{array}{l}\text { 18.How often have you been pleased with the } \\
\text { behavior of a person with disabilities? }\end{array}$ & 2.15 & 1.23 & 98 \\
\hline $\begin{array}{l}\text { 19.How often did you have pleasant relationships } \\
\text { with people with disabilities? }\end{array}$ & 2.13 & 1.163 & 98 \\
\hline $\begin{array}{l}\text { 20.How often did you have unpleasant } \\
\text { relationships with people with disabilities? }\end{array}$ & 1.46 & 0.706 & 98 \\
\hline Source: Authors & & & \\
\hline
\end{tabular}

The results presented in Table 5 provide grounds for concluding that as a whole the Contacts with disabled people scale has an excellent internal coherence, expressed in the high values of the Cornbrash's alpha, and of the average correlation between the items. The coefficient alpha has a very high value -0.915 , while the value of the average correlation between items is low -0.353 , which is a sign of a very good reliability of the scale as a hole.

This survey provides us with evidence that the Bulgarian and Czech students demonstrate positive attitude towards situations in which either it is not necessary (can be avoided) to communicate constantly with people with disabilities, or towards situations requiring communication on equal terms.

However, in fact, the data collected by the survey shows generally more positive and more tolerant attitude of the students, who will be future psychologists and pedagogues, towards people with disability and readiness to communicate with them.

Table 5: Results of the reliability analysis of the Contacts with disabled people scale

\begin{tabular}{||c|c|c|c|}
\hline $\begin{array}{c}\text { Cornbrash's alpha }=0.915 \\
\text { Average correlation between items }=0.353\end{array}$ & $\begin{array}{c}\text { Average raw } \\
\text { score after } \\
\text { removal of the } \\
\text { respective item }\end{array}$ & $\begin{array}{c}\text { Correlation } \\
\text { coefficient } \\
\text { after removal } \\
\text { of the } \\
\text { respective } \\
\text { item }\end{array}$ & $\begin{array}{c}\text { Cornbrash's } \\
\text { alpha after } \\
\text { removal of the } \\
\text { respective } \\
\text { item }\end{array}$ \\
\cline { 1 - 4 } $\begin{array}{l}\text { 1. How often did you have a long conversation } \\
\text { with a person with disabilities? }\end{array}$ & 33.00 & .710 & .907 \\
\hline
\end{tabular}




\begin{tabular}{|c|c|c|c|}
\hline $\begin{array}{l}\text { 2.How often did you have a written } \\
\text { communication with people with disabilities? }\end{array}$ & 34.29 & .600 & .911 \\
\hline $\begin{array}{l}\text { 3.How often did you have a meal with people with } \\
\text { physical disabilities? }\end{array}$ & 33.81 & .723 & .907 \\
\hline $\begin{array}{l}\text { 4.How often have you been a donor to } \\
\text { organizations that help to people with disabilities? }\end{array}$ & 33.55 & .358 & .916 \\
\hline $\begin{array}{l}\text { 5.How often do people with disabilities discuss } \\
\text { their life or their problems with you? }\end{array}$ & 33.76 & .740 & .906 \\
\hline $\begin{array}{l}\text { 6.How often do you discuss your life or your } \\
\text { problems with people with disabilities? }\end{array}$ & 34.08 & .558 & .911 \\
\hline $\begin{array}{l}\text { 7.How often have you tried to help people with } \\
\text { disabilities to solve their problems? }\end{array}$ & 33.35 & .570 & .911 \\
\hline $\begin{array}{l}\text { 8.How often have people with disabilities tried to } \\
\text { help you to solve your problems? }\end{array}$ & 34.22 & .548 & .911 \\
\hline $\begin{array}{l}\text { 9.How often have you worked with clients, } \\
\text { students or patients with disabilities in your work? }\end{array}$ & 33.60 & .516 & .912 \\
\hline $\begin{array}{l}\text { 10.How often have you worked with a person with } \\
\text { disabilities? }\end{array}$ & 33.69 & .642 & .909 \\
\hline $\begin{array}{l}\text { 11. How often does a friend with disabilities visit } \\
\text { your home? }\end{array}$ & 34.28 & .530 & .912 \\
\hline $\begin{array}{l}\text { 12.How often have you visited people with } \\
\text { disabilities in their homes? }\end{array}$ & 33.80 & .705 & .907 \\
\hline $\begin{array}{l}\text { 13. How often do you meet with a person with } \\
\text { disabilities who you like? }\end{array}$ & 33.63 & .705 & .907 \\
\hline $\begin{array}{l}\text { 14.How often do you meet with a person with } \\
\text { disabilities who you do not like? }\end{array}$ & 34.16 & .518 & .912 \\
\hline $\begin{array}{l}\text { 15.How often do you meet with a person with } \\
\text { disabilities who you respect? }\end{array}$ & 33.56 & .702 & .907 \\
\hline $\begin{array}{l}\text { 16. How often do you meet with a person with } \\
\text { disabilities who you pity? }\end{array}$ & 33.68 & .445 & .914 \\
\hline $\begin{array}{l}\text { 17.How often are you irritated or feel confused by } \\
\text { the behavior of a person with disabilities? }\end{array}$ & 33.78 & .314 & .916 \\
\hline $\begin{array}{l}\text { 18. How often have you been pleased with the } \\
\text { behavior of a person with disabilities? }\end{array}$ & 33.38 & .456 & .914 \\
\hline $\begin{array}{l}\text { 19.How often did you have pleasant relationships } \\
\text { with people with disabilities? }\end{array}$ & 33.40 & .736 & .906 \\
\hline $\begin{array}{l}\text { 20.How often did you have unpleasant } \\
\text { relationships with people with disabilities? }\end{array}$ & 34.07 & .308 & .915 \\
\hline
\end{tabular}

\section{Conclusion}

The results from the empirical survey disclose interesting tendencies in the Bulgarian and Czech student society regarding the contacts with people with disabilities.

1. The used scale is reliable.

2. The tolerant attitude towards disabled people increases, although at times it is still patronizing. 
3. Students demonstrate more positive attitude towards situations involving joint events assisting the students.

In society, there is a considerable shortage of information about given categories of disabled people. These shortages of information produce wrong generalizations, which turn into prejudice and negative stereotypes thus leading to discrimination practices, and eventually to marginalization and reducing the contacts with people with disabilities.

Regardless of the public efforts, the information about disabled people is insufficient or abstruse, and this leads to lesser contacts with people with disabilities.

The fact that the students have communicated with people with disabilities, is an indication that the public attitude is more positive, and there are conditions for integration of disabled people into society. These people are their colleagues in the university; they are neighbors who can be seen on the street, i.e. there is a positive attitude and a situation helping the integration of people with disabilities.

There is not enough information and events in the universities which could engage students too, although they express willingness to communicate with people with disabilities.

It is easier to reject contacts with a person with whom you did not have a close relationship, than with a person with whom you have shared, you have ate together, and whom you have helped. In order to achieve a better level of integration of the people with disabilities it is necessary to give them the possibility to present themselves in society.

On the basis of the conclusions made, we can formulate the following recommendations towards institutions involved in forming the attitudes towards people with disabilities and the integrated education.

1. When the institutions are planning reforms in education, to take into account the needs of the children with physical, sensor, mental and combined disabilities of integrated and inclusive education, by developing a long-term strategy for inclusive education for these children, based on the international experience whilst in the same time preserving all beneficial national traditions and specifics.

2. Differentiated social policies depending on the needs of people with disabilities.

3. Extensive information campaigns with the purpose of popularizing the achievements of disabled people and presenting disabled people into society.

\section{Acknowledgement}

The article is funded by the project DTK $02 / 8$ "Personal and national identity and social environment", Bulgarian Science Fund, Ministry of Education, Youth and Science.

\section{References}

Ajzen, I. \& Fishbein, M. (2000) Attitudes and the attitude - behavior relation: Reasoned and automatic processes. European review of social psychology, 1 (3).

Daruwalla, P. \& Darcy, S. (2005). Personal and social attitudes to disability. Annals of Tourism Research, Vol. 32, No. 3, pp. 549-570 http://dx.doi.org/10.1016/j.annals.2004.10.008

Festinger, L. (1962). Cognitive dissonance. Scientific American, 207 (4), pp. 93 - 107. http://dx.doi.org/10.1038/scientificamerican1062-93 
Likert, R. (1932). Technique for the Measurement of Attitudes. Archives of Psychology, 140, 5-55

Mann, H. \& Whitney, D. (1947). On a test of whether one of two random variables is stochastically larger than the other. Annals of Mathematical Statistics, Vol. 18, pp.50-60.

http://dx.doi.org/10.1214/aoms/1177730491

Sidorenko, E.(2007). Methods of mathematical processing in psychology. Saint Petersburg, Russia: Rech'. PMCid:2242789

Stamatov, R. \& Enchev, N. (2012). Human behavior. Plovdiv, Bulgaria: Publishing house Hermes.

Wilcoxon, F. (1945). Individual Comparisons by Ranking Methods. Biometrics Bulletin, Vol. 1, No. 6, pp. 80-83. http://dx.doi.org/10.2307/3001968

Yuker, H. \& Hurley, M. (1987). Contact with and attitudes toward persons with disabilities. Rehabilitation Psychology, 32 (3), pp.145-154. 